\title{
Pemikiran Pendidikan Agama Islam dalam Perspektif Prof. Achmadi
}

\author{
Ema Siti Rohyani \\ MTs N Parakan, Kecamatan Parakan, Kabupaten Temanggung \\ Email: emasr@gmail.com \\ DOI: $10.18326 /$ mudarrisa.v7i2.173-200
}

\begin{abstract}
Penelitian ini mencoba untuk mengetahui konsep pendidikan Islam dalam perspektif Prof. Achmadi. Studi ini berfokus pada: 1) bagaimana posisi pendidikan Islam dalam kerangka pendidikan nasional; 2) bagaimana dasar dan tujuan pendidikan Islam; 3) bagaimana pandangan Achmadi menggunakan pendekatan pendidikan Islam; 4) bagaimana isi pendidikan Islam; 5) bagaimana relevansi pendidikan Islam dengan konteks saat ini. Analisis ini menggunakan metode analisis isi. Berdasarkan hasil, maka dapat dirumuskan bahwa posisi pendidikan Islam di Indonesia menjadi semakin terlihat dengan adanya UU Sistem Pendidikan Nasional Nomor 20 Tahun 2003. Sejalan dengan hal tersebut pendidikan agama Islam menurut Prof. Achmadi, baik landasan maupun tujuan, sesuai dengan nilai-nilai Ilahi. Pemikiran Prof. Achmadi sebagai pendekatan fungsional, pendekatan humanis, pendekatan rasional kritis, pendekatan budaya dalam studi Islam bisa dilakukan untuk memajukan pendidikan Islam di Indonesia dalam jangka panjang. Materi pendidikan agama Islam menurut Prof. Achmadi terdiri dari pengetahuan abadi dan pengetahuan yang diperoleh. Pendidikan agama Islam menurut Prof. Achmadi sangat sesuai dengan konteks saat ini, tapi masih memerlukan
\end{abstract}


peningkatan kualitas sumber daya manusia sebagai bentuk pendidikan ideologi yang berkembang sesuai dengan perubahan zaman.

This study seeks the concept of Islamic education in the perspective of Prof. Achmadi. The study focuses on: 1) how is the Islamic education position within the framework of national education; 2) how is the foundation and purpose of Islamic education; 3) how Achmadi views on the approach in Islamic education; 4) how is the content of Islamic education; 5) how is the relevance of Islamic education with the context of nowadays. This study applies a content analysis method. The results show that the position of Islamic education in Indonesia takes part more and more to the presence of the Law of National Education System No. 20/2003. In line with the law, he argues that Islamic religious education includes foundation and purpose in accordance with the values of the Divine. Prof. Achmadi's thought as functional, humanist, critical rational, and cultural approach in Islamic studies can be implemented to promote long term Islamic education in Indonesia. He proposes that Islamic religious education materials consist of perennial and gained knowledge. It is relevant to the today context, but still requires improvement to the quality of human resources as a form of ideological education which is developed in accordance with the times changing.

Kata Kunci : pendidikan islam, sudut pandang, Prof. Achmadi

\section{Pendahuluan}

Dalam situasi modernitas, islam juga semakin dituntut peranannya untuk menjadi pemandu arah kehidupan manusia. Pendidikan agama Islam diharapkan memberikan jawaban terhadap masalah kehidupan umat Islam yang berada di dunia global tersebut. Secara normatif, pendidikan agama Islam mengandung nilai-nilai universal yang memberikan resep mujarab untuk solusi problem manusia. (Nata, 2010:433). 
Dalam ranah ilmiah, banyak literatur yang berbicara tentang pendidikan agama Islam di Indonesia dari berbagai pendekatan, sebagai contoh: Amin Abdullah, Azumardi Azra, Noeng Muhadjir, Imam Suprayogo, Abuddin Nata dan salah satunya adalah Prof. Achmadi.

Prof. Achmadi dalam kiprahnya di dunia pendidikan berkehendak untuk mewujudkan pendidikan agama Islam yang lebih dari sekedar masalah ubudiyah dan fiqhiyah. Ia juga ingin mendudukkan pendidikan Islam yang bukan sekedar memenuhi aspek normatif, tetapi juga historis. Pendidikan agama Islam tidak hanya membahas tentang suatu ajaran, tetapi membahas pula peristiwa dengan memperlihatkan unsur tempat, waktu, objek, latar belakang, dan pelaku dari peristiwa.

Oleh karena itu, pemikiran Prof. Achmadi tentang Pendidikan Agama Islam perlu dikaji lebih dalam. Pemikiran itu menjadi penting bukan hanya bagi muslim Jawa Tengah, tetapi juga nusantara. Adapun hal-hal yang perlu dikaji lebih dalam diantaranya posisi Pendidikan Agama Islam dalam kerangka pendidikan nasional menurut Prof. Achmadi, pandangan Prof. Achmadi tentang dasar dan tujuan Pendidikan Agama Islam, pandangan Prof. Achmadi tentang pendekatan dalam Pendidikan Agama Islam, pandangan Prof. Achmadi tentang materi Pendidikan Agama Islam, dan relevansi pemikiran pendidikan agama Islam Prof. Achmadi dengan konteks pendidikan Islam sekarang.

\section{Biografi Prof. Achmadi}

Dengan memahami biografi, kita dapat mengetahui bagaimana pola pikir seseorang terbentuk. Penulis berupaya untuk memaparkan 
biografi Prof. Achmadi sehingga mampu menghasilkan suatu analisis dan kesimpulan yang komprehensif.

Prof. Achmadi Lahir di Yogyakarta pada tanggal 4 Oktober 1944, saat berumur enam tahun dia memulai belajar, dimulai dari SD Muhammadiyyah Karangkajen Yogyakarta tahun 1957 sambil nyantri di Pondok Pesantren Krapyak yang diasuh oleh KH Abdul Kodir, dia kemudian melanjutkan pada Pendidikan Guru Agama Negeri (PGAN) Yogyakarta tahun 1963, tamat dari PGAN, dia melanjutkan studinya di IAIN Sunan Kalijaga (sekarang UIN Sunan Kalijaga) Yogyakarta (Munir, 2005:48).

Di sela-sela kesibukannya, Dia aktif di berbagai organisasi kemahasiswaan. Diantaranya pernah menjabat sebagai ketua pimpinan cabang Pemuda Muhammadiyyah Mergangsan Yogyakarta tahun 19631971 dan menjadi anggota Himpunan Mahasiswa Islam (HMI) DIY (1968-1971), di samping itu masih banyak pengalaman dalam berorganisasi yang ditekuni oleh Prof. Achmadi.

Pada tahun 1970 Prof. Achmadi menjadi sarjana lengkap pada Fakultas Tarbiyah IAIN Sunan Kalijaga pada kota yang sama setelah selasai menyelesaikan Strata I (SI) pada tahun 1973, dia menyelesaikan Post Graduate Course (PGC) Ilmu Pendidikan IAIN Sunan Kalijaga Yogyakarta 1973. Pada tanggal 8 Januari 2005 dia memperoleh gelar Profesor dalam bidang Ilmu Pendidikan Islam (IPI).

Sebagai seorang akademisi, Prof. Achmadi aktif dalam kegiatan ilmiah. Karya ilmiah yang dihasilkan diantaranya Ilmu Pendidikan Sebuah Pengantar, Islam Sebagai Paradigma Ilmu Pendidikan, Dasar- 
Dasar Pelaksanaan Pendidikan Agama di Sekolah dalam PBM Pendidikan Agama di Sekolah, Refleksi Pemikiran Muhammadiyah Sebuah Telaah Histories dalam Reaktualisasi Tajdid Muhammadiyah, Reformasi Sistem Pendidikan Agama Islam dalam Era Reformasi: Telaah Filsafat, dalam Pendidikan Islam, Demokratisasi, dan Masyarakat Madani, Islam Sebagai Alternatif Paradigma Ilmu Pendidikan dalam Paradigma Pendidikan Pendidikan Islam, dan Ideologi Pendidikan Islam, Paradigma Humanis Teosentris.

Selain karya ilmiah, Prof. Achmadi juga produktif dalam menulis artikel. Artikel Majalah/Jurnal yang dihasilkan diantaranya Pendidikan Integratif Wawasan ilmiah dan Agama dalam Pendidikan, Politik, Agama, dan Pendidikan Agama, Klasifikasi Ilmu Pengetahuan Islam, Ali Syari'ati Pemikiran dan Cita-citanya dalam perspektif Pembaharuan Pemikiran Islam, Ideologisasi dan Transformasi Pemikiran Keagamaan Muhammadiyah, Studi Islam di Belanda serta makalah-makalah yang disampaikan dalam forum baik nasional maupun internasional.

\section{Metode Penelitian}

Metode yang digunakan dalam penelitian ini merupakan metode kualitatif. Pendekatan kualitati adalah prosedur penelitian yang menghasilkan data deskriptif (data yang dikumpulkan berupa kata-kata, gambar, dan bukan angka-angka) (Moleong, 2006: 76).

Sedangkan jenis penelitian yang peneliti gunakan adalaha Analisis Isi (Content Analysis) yang artinya suatu model yang diapakai untuk meneliti dokumentasi data yang berupa teks, gambar, symbol dan 
sebagainya. Sebagai suatu teknik penelitian, analisis isi mencakup prosedur-prosedur khusus untuk pemrosesan dalam data ilmiah dengan tujuan memberikan pengetahuanm membuka wawasan baru dan menyajikan fakta. Selain itu digunakannya analisis isi dalam penelitian ini untuk meneliti dokumen yang berupa buku-buku karya Prof. Achmadi tentang Pendidikan Islam, dengan menggunakan analisis isi secara kualitatif terhadap buku-buku tersebut, peneliti mampu mengetahui bagaimana perspektif Prof. Achmadi terhadap pendidikan Islam di Indonesia.

\section{Perspektif Prof. Achmadi terhadap Pendidikan Islam}

Melihat berbagai karya yang dihasilkan Prof. Achmadi, dapat kita simpulkan bahwa Prof. Achmadi sangat concern dengan pendidikan agama. Pendidikan agama sangat penting dan strategis dalam rangka menanamkan nilai-nilai spiritual Islam, tetapi hal ini baru berupakan sebagian dari seluruh kerangka pendidikan Islam. Pengertian pendidikan agama Islam menurut Achmadi (1987:10) adalah "usaha yang lebih khusus ditekankan untuk mengembangkan fitrah keberagaman dan sumber daya insani agar lebih mampu memahami, menghayati dan mengamalkan ajaran-ajaran Islam”.

Implikasi dari definisi ini adalah pendidikan agama Islam merupakan komponen yang tidak terpisahkan dari sistem pendidikan Islam. Bahkan tidak berlebihan kalau dikatakan bahwa pendidikan agama Islam berfungsi sebagai jalur pengintegrasian wawasan Islam pada bidang-bidang studi yang lain. Implikasi lebih lanjut pendidikan agama 
harus sudah dilaksanakan sejak dini sebelum peserta didik memperoleh pendidikan atau pengajaran ilmu-ilmu yang lain. Pendidikan agama menurut Ibnu Khaldun lebih menitik beratkan pada pengajaran al-Qur'an, karena al-Qur'an merupakan ilmu yang pertama kali diajarkan kepada anak-anak. Dengan mengajarkan al-Qur'an kepada anak-anak maka akan dapat menumbuhkan perasaan keagamaan (Achmadi, 1987:11).

Pendidikan agama perlu dirumuskan secara sistemik terutama tentang kehidupan keagamaan. Keputusan sistemik kehidupan keagamaan ialah sesuatu yang dirancang atau difungsikan dalam interpendensi untuk seluruh satuan termasuk subsatuannya. Para proklamator pendiri Republik Indonesia telah membuat sistem kehidupan keagamaan dalam UUD 1945 dan dimuat berulang kali dalam pembukaan UUD 1945.

Sila pertama UUD 45 menjelaskan bahwa dengan sila Ketuhanan Yang Maha Esa mengandung makna kewajiban pemerintah dan para penyelenggara lainnya untuk memelihara budi pekerti kemanusiaan yang luhur dan memegang teguh cita-cita moral yang luhur. Untuk mewujudkan amanat dalam UUD 1945 itu, pemeliharaan budi pekerti kemanusiaan yang luhur tidak dapat dilepaskan dari usaha membina dan mengembangkan kehidupan beragama bangsa Indonesia, bahkan hal tersebut merupakan bagian yang tidak terpisahkan dari ajaran agama (Achmadi, 1992:105).

Dalam usaha pembinaan dan pengembangan kehidupan keagamaan, negara/pemerintah tidak hanya menjamin kebebasan tiap penduduk untuk memeluk agamanya masing-masing dan untuk beribadah 
menurut agama dan kepercayaannya. Agama juga sekaligus menjamin, melindungi, membina mengembangkan serta memberikan bimbingan dan pengarahan agar kehidupan beragama lebih berkembang, bergairah, dan bersemarak, serasi dengan kebijaksanaan pemerintah dalam membina kehidupan berbangsa dan bernegara berdasarkan Pancasila.

Politisi awal kemerdekaan telah mengoperasionalkan keputusan sistemik kehidupan keagamaan dalam berbagai lembaga pemerintahan. Tampak jelas bahwa sejak awal Republik Proklamasi 1945 telah diupayakan pengintegrasian urusan keagamaan dalam pemerintahan Indonesia, seperti adanya Departemen Agama di samping departemen yang lain, Peradilan Agama. Departemen Agama yang sekarang menjadi Kementerian Agama dipandang sebagai institusi keagamaan tertinggi dalam organisasi pemerintahan yang memiliki tugas pokok menyelenggarakan sebagian dari tugas umum pemerintahan dan pembangunan di bidang agama (Achmadi, 1992:106).

Tujuan pembangunan nasional juga menyebutkan harus mewujudkan suatu masyarakat adil dan makmur yang merata material dan spiritual berdasarkan Pancasila. Makna spiritual dalam bahasa adalah lawan dari profan atau sekular, ini berarti bahwa kemajuan yang diharapkan dari pembangunan bukan kemajuan yang berorientasi modern yang sekular, tetapi modern yang dijiwai oleh nilai-nilai Ilahi.

\section{Posisi Pendidikan Agama Islam dalam Pendidikan Nasional}

Modal dasar pembangunan disebutkan bahwa kepercayaan dan ketaqwaan kepada Tuhan Yang Maha Esa merupakan tenaga penggerak 
yang tidak ternilai harganya bagi pengisian aspirasi-aspirasi bangsa. Pendidikan agama merupakan bagian pendidikan yang amat penting yang berkenaan dengan aspek-aspek sikap dan nilai, keimanan dan ketaqwaan. Hal ini berarti pula bahwa keberhasilan pendidikan nasional tidak dapat tercapai tanpa pendidikan agama, karena keimanan dan ketaqwaan terhadap Tuhan Yang Maha Esa hanya dapat dicapai melalui pendidikan agama (Achmadi, 1992:107).

Pendidikan agama Islam sebenarnya sudah ada jauh sebelum kemerdekaan. Namun karena politik pendidikan pemerintah penjajah (Belanda), maka sekolah-sekolah negeri tidak diberikan pendidikan agama. Didorong oleh semangat kebangsaan yang dijiwai oleh ruhul Islam "Muhammadiyah" sebagai gerakan Islam merintis jalan pendidikan agama di sekolah-sekolah umum yang diselenggarakannya.

Kedudukan pendidikan agama di sekolah umum dapat ditinjau dari segi keputusan-keputusan yuridis sebagai dasar hukumnya. Secara kronologik dapat dikemukakan diantaranya Keputusan Menteri Agama No. 1185/K.J. tgl. 20-11-1946 tentang penyempurnaan organisasi kementerian agama, dengan mengadakan bagian $\mathrm{C}$ yang bertugas melaksanakan kewajiban-kewajiban, Peraturan bersama Menteri Agama dan Menteri PP dan K nomor: 1142/Bhg. A (pengajaran)/Nomor: 11285/KJ (Agama) tgl. 2 Desember 1946, tentang ketentuan adanya pelajaran agama di sekolah rakyat sejak kelas IV, Undang-Undang Nomor 4/1950 jo. Nomor 12/1954 tentang Dasar-Dasar Pendidikan dan Pengajaran di sekolah yang ada pada Bab XII pasal 20, Peraturan bersama Menteri Pendidikan, Pengajaran dan Kebudayaan dan Menteri 
Agama No. 17678/Ka. Tgl. 16 Juli 1951 (pendidikan)/No. K.I/1980 tgl. 16 Juli 1951 (Agama) tentang pedoman penyelenggaraan pendidikan agama, yang merupakan realisasi dari pasal 20 UU No. 4/1950. (Achmadi, 1992:108).

Lingkup pendidikan agama Islam pada lembaga pendidikan atau perguruan agama meliputi Madrasah Diniyah, Raudhatul Athfal, Madrasah Ibtidaiyah, Madrasah Tsanawiyah, Madrasah Aliyah, Pendidikan Guru Agama, Pondok Pesantren dan Perguruan Tinggi Agama Islam baik negeri maupun swasta. Sebagian terbesar lembaga pendidikan agama berstatus swasta. Hanya 0,37\% dari sekolah agama yang berstatus negeri dan hanya 4,5\% dari murid-murid berada pada sekolah negeri. Ini berarti bahwa kehadiran sekolah-sekolah agama Islam berakar pada hasrat masyarakat sendiri (Achmadi, 1992:109).

Keberadaan perguruan-perguruan agama Islam memiliki latar belakang sejarah yang panjang sejak zaman penjajahan Belanda. Masyarakat Indonesia terkenal sebagai masyarakat yang agamis yang mayoritas adalah umat Islam. Dalam kegiatan keagamaan dan kemasyarakatan peran ulama' sangat dominan. Kaum ulama secara diamdiam melakukan perlawanan terhadap pemerintah Belanda dengan menumbuhkan kondisi yang berlainan antara aspirasi kaum muslimin dengan kebijaksanaan pemerintah Belanda.

Kebijaksanaan pemerintah Belanda tersebut dilaksanakan dengan membuka berbagai jenis sekolah untuk rakyat Indonesia, yang bertujuan secara formal memenuhi keperluan pemerintah dan onderneming terhadap tenaga kerja yang terdidik. Tetapi sebenarnya mengandung 
tujuan untuk menjauhkan pemuda-pemuda Indonesia dari masyarakat dan agama (Islam), dan sebaliknya mendekatkan kepada kebudayaan barat (Belanda). Kebijaksanaan pemerintah Belanda ini adalah berpedoman kepada "Etische Politiek".

Untuk mengimbangi kebijaksanaan pemerintah Belanda tersebut, maka para ulama' mengadakan usaha penyempurnaan dan memperkembangkan lembaga pendidikan pesantren menjadi Madrasah, di mana diajarkan ilmu pengetahuan umum di samping ilmu pengetahuan agama. Dengan demikian diharapkan akan lahir sekelompok ulama' intelek yang mampu mengimbangi produk pendidikan Belanda tersebut. dalam pertumbuhan selanjutnya sistempendidikan madrasah berkembang sampai ke tingkat Perguruan Tinggi Agama Islam (Achmadi, 1992:110).

Setelah zaman kemerdekaan, kecenderungan masyarakat mendirikan madrasah tetap terus berlanjut walaupun dengan motivasi yang berbeda dengan apa yang dilakukan pada zaman penjajahan. Motivasi mendirikan madrasah pada zaman kemerdekaan adalah untuk mengisi kemerdekaan dan ikut berkiprah dalam pembangunan dengan tetap melestarikan dan mengembangkan ajaran Islam.

Kenyataan bahwa perguruan agama Islam mayoritas berstatus swasta secara sederhana dapat diartikan andil umat Islam dalam ikut mencerdaskan bangsa dan sekaligus meningkatkan ketaqwaan Tuhan Yang Maha Esa cukup besar. Oleh karena itu pantas apabila perhatian pemerintah dalam upaya mengembangkan dan meningkatkan mutu perguruan agama Islam juga cukup besar. 
Salah satu hal yang perlu dicatat mengenai perkembangan penyelenggaraan sekolah-sekolah agama adalah lahirnya Keppres No. 34 tahun 1974 tentang tanggung jawab fungsional pendidikan dan latihan serta Inpres No. 15 tahun 1974 tentang pelaksanaan Keppres tersebut, yang berisi sebagai berikut: Pembinaan pendidikan umum menjadi tanggung jawab Menteri $\mathrm{P}$ dan $\mathrm{K}$ sedang pendidikan agama menjadi tanggung jawab Menteri Agama Untuk melaksanakan Keppres No. 34 dan Inpres No. 15 tahun 1974 dengan sebaik-baiknya ada kerja sama antara Departemen $\mathrm{P}$ dan $\mathrm{K}$, Departemen Negeri dan Departemen Agama.

Sebagai pelaksanaan dari Keppres tersebut lahirlah Keputusan Bersama Tiga Menteri, yaitu Menteri Agama, Menteri P dan K dan Menteri dalam Negeri tahun 1975 tentnag peningkatan mutu pendidikan pada madrasah. Maksud dan tujuan peningkatan mutu pendidikan pada madrasah adalah agar tingkat mata pelajaran umum dari madrasah dapat mencapai tingkat yang sama dengan tingkat mata pelajaran umum di sekolah-sekolah umum yang setingkat, sehingga hal tersebut dapat berimplikasi sebagai berikut:

Ijazah madrasah dapat mempunyai nilai yang sama dengan Ijazah sekolah umum yang setingkat, Lulusan madrasah dapat melanjutkan ke sekolah umum setingkat lebih atas, dan Siswa madrasah dapat berpindah ke sekolah umum yang setingkat.

Kebijakan semacam ini menunjukkan dengan jelas bahwa pendidikan agama Islam merupakan subsistem dari pendidikan nasional. Adapun dalam pelaksanaannya sering mengalami berbagai hambatan dan 
kekurangan, itu masalah lain atau mungkin hanya sekedar masalah teknis (Achmadi, 1992:112).

Kelembagaan Pendidikan agama Islam Tingkat Tinggi. Berbicara tentang pendidikan agama Islam tingkat tinggi dewasa ini kiranya cukup representatif apabila berbicara mengenai Institut Agama Islam Negeri (IAIN). Adapun perguruan Tinggi Agama Islam yang lain (swasta) hampir semuanya pada tahun 1992 menggunakan standar IAIN.

Catatan sejarah mengenai berdirinya IAIN adalah masyarakat Indonesia telah lama mencita-citakan adanya suatu perguruan tinggi Islam untuk menampung pemuda-pemuda dalam mendalami agama Islam. Cita-cita tersebut sebelumnya hanya dapat dicapai melalui pendidikan di Timur Tengah. Keinginan pemuda-pemuda timbul sebagai manifestasi kebutuhan masyarakat terhadap ahli agama Islam (ulama') yang akan memimpin dalam kegiatan keagamaan dan kemasyarakatan.

Untuk menampung keinginan masyarakat tersebut diadakan usaha mendirikan Pesantren Luhur oleh beberapa pemuka masyarakat yang diketuai oleh Dr. Satiman. Cita-cita pendirian Pesantren Luhur terus berkembang dan akhirnya menjelma dalam bentuk Sekolah Tinggi Islam (STI) pada bulan Juli 1945 di Jakarta. Karena situasi perjuangan dalam menegakkan dan mempertahankan kemerdekaan Indonesia, maka STI ikut hijrah ke Yogyakarta. Setelah ibukota Republik Indonesia pindah ke Yogyakarta, kemudian STI berubah menjadi Universitas Islam Indonesia (UII) dengan membuka tiga fakultas yaitu: Fakultas IlmuAgama, Fakultas Ekonomi, dan Fakultas Hukum dan Kemasyarakatan (Achmadi, 1992:112-113). 
Berdasarkan peraturan pemerintah No. 34 tahun 1950, didirikanlah Perguruan Tinggi Agama Islam Negeri (PTAIN) yang berasal dari Fakultas Agama Universitas Islam Indonesia. Pendirian PTAIN ini merupakan anugerah pemerintah RI terhadap perjuangan umat Islam dalam menegakkan dan mempertahankan kemerdekaan Indonesia. Kemudian di Jakarta didirikan pula Akademi Dinas Ilmu Agama (ADIA) dengan diintegrasikan menjadi Institut Agama Islam Negeri (IAIN) berdasarkan peraturan Presiden No. 11 tahun 1960.

Keberadaan IAIN tahun 1960 secara kuantitatif sejak berdirinya sampai sekarang telah berkembang menjadi 14 IAIN yang tersebar di seluruh Indonesia (pada tahun 1992). Untuk lebih memantapkan keberadaan IAIN sebagai perguruan tinggi negeri yang setara dengan perguruan tinggi lainnya pemerintah memandang perlu adanya dasar hukum yang lebih kokoh.

Awalnya berdirinya dasar hukum bagi keberadaan IAIN Peraturan Presiden, mulai tahun 1985 dikukuhkan dengan Peraturan Pemerintah, yaitu Peraturan Pemerintah No. 33 th. 1985 tentang Pokok-pokok Organisasi Institut Agama Islam Negeri. Pokok-pokok Organisasi tersebut dimaksudkan untuk lebih meningkatkan penyelenggaraan dan pembinaan IAIN sebagai pendidikan Tinggi Agama Islam Negeri. Dalam peraturan pemerintah tersebut ditegaskan mengenai kedudukan dan tugas pokok IAIN yaitu kedudukan IAIN adalah unit organisasi di lingkungan Departemen Agama yang dipimpin oleh Rektor yang berada di bawah dan tanggung jawab langsung kepada Menteri Agama” (Pasal 2 ayat 2). Sedangkan tugas pokok IAIN adalah menyelenggarakan pendidikan dan 
pengajaran di atas perguruan tingkat menengah yang berdasarkan kebudayaan dan kebangsaan Indonesia dan secara ilmiah memberikan pendidikan dan pengajaran, penelitian, dan pengabdian pada masyarakat di bidang ilmu pengetahuan agama Islam sesuai dengan peraturan perundang-undangan yang berlaku.

Dengan diberlakukannya Peraturan Pemerintah No. 33 th. 1985 tersebut dimungkinkan kiprah IAIN semakin mantap dalam menekuni bidang tugasnya dalam ilmu pengetahuan agama Islam. Hal tersebut dikarenakan IAIN memiliki posisi dan kesempatan yang sama dengan perguruan tinggi negeri lainnya. Dengan ini diharapkan pula mampu melahirkan intelektual yang bersama-sama dengan keterikatan yang serius kepada Islam.

Selama ini ada semacam kekhawatiran terhadap "disintegrasi" antara agama Islam (wahyu) dengan ilmu pengetahuan rasional. Hal tersebut mengakibatkan dikotomi sistem pendidikan Islam yang kemudian oleh para cendekiawan Islam (misalnya Raji’ Al-Faruqi) harus diupayakan pengintegrasian kembali dengan langkah awal Islamisasi pengetahuan. Dari hal itu maka diharapkan nantinya IAIN dapat menjembatani upaya besar dan luhur tersebut. karena (meminjam istilah Fazlur Rahman) justru pengemban-pengemban ilmu pengetahuan keislamanlah yang harus memikul tanggung jawab utama untuk mengislamkan ilmu pengetahuan sekuler dengan upaya-upaya intelektual yang kreatif (Achmadi, 1992:114).

Pondok pesantren sebagai lembaga pendidikan dan penyebaran Islam telah lahir dan berkembang semenjak masa kedatangan Islam di 
Indonesia. Lazimnya pengertian pondok pesantren ialah lembaga pendidikan Islam dengan kyai sebagai tokoh sentralnya dan masjid sebagai pusat lembaganya. Pendidikan yang diberikan di pondok pesantren adalah pendidikan agama dan akhlak (mental).

Bentuknya yang tradisional menandakan metode pengajarannya menggunakan metode waton atau sorogan dan bandongan. Dalam perkembangannya, sebagai akibat pengaruh sistem sekolah maka selanjutnya menggunakan bentuk madrasah dengan sistem klasikal. Walaupun sampai saat ini pondok pesantren sudah mengalami banyak perubahan dan perkembangan, namun pondok pesantren tetap memiliki ciri khusus yang berbeda dengan sekolah. Keunikan pondok pesantren ialah memiliki ciri khusus, semacam kepribadian yang diwarnai oleh kharasteristik pribadi sang kyai, unsur-unsur pimpinan pesantren, bahkan juga aliran keagamaan tertentu yang dianut.

Perubahan pesantren menjadi madrasah didasari oleh pendapatpendapat pakar pendidikan agama. Mukti Ali mengemukakan bahwa "Madrasah dalam pesantren adalah sistem pengajaran dan pendidikan agama yang paling baik." Pernyataan demikian kiranya perlu diuji keabsahannya. Misalnya perlu ditinjau dari sudut apa hal yang dianggap paling baik, apakah karena ketundukannya pada kyai, taatnya menunaikan amalan-amalan ubudiyah, kezuhudannya, atau kemampuan membaca kitab kuning.

Akan lebih realistis kalau dikatakan bahwa madrasah dalam pesantren memiliki kelebihan juga kekurangan sebagai sistem pendidikan agama. sehingga agar terhindar dari sikap memitoskan pesantren yang 
dapat menutup alternatif lain. Dengan segala kelebihan dan kekurangannya, yang jelas sejak beberapa tahun lalu sampai dewasa ini pemerintah cukup besar perhatian dan bantuannya kepada pondok pesantren. Hal ini karena pondok pesantren dinilai memiliki potensi dalam pembangunan (Achmadi, 1992:115).

Kajian tentang pendidikan agama Islam dalam masyarakat sanagt diperlukan. Baik secara historis maupun sosiologis perkembangan Islam di Indonesia banyak ditentukan oleh lembaga pendidikan dalam masyarakat terutama oleh pendidikan yang bersifat informal maupun non-formal dengan berbagai medianya, baik melalui komunikasi antara individu maupun secara kelompok. Di zaman modern ini media komunikasi yang dapat dimanfaatkan untuk menyampaikan pesan-pesan agama semakin canggih, baik melalui media cetak seperti koran, majalah dan berbagai penerbitan, juga melalui media elektronika seperti radio, TV dan film.

Media tradisional yang masih tetap aktual adalah "Pengajian". Pengajian dari berbagai kelompok; anak-anak, remaja dan dewasa yang dikelola oleh majelis ta'lim atau organisasi-organisasi Islam, bahkan secara resmi diselenggarakan oleh instansi pemerintah kelurahan sampai pusat. Selain itu, masjid sebagai salah satu pusat pendidikan Islam semakin banyak, hampir setiap kelurahan memiliki masjid. Oleh masyarakat masjid digunakan untuk beribadah dan untuk kegiatan pendidikan keagamaan lainnya. Semua yang tersebut diatas tumbuh berkembang sedemikian rupa atas dorongan dan prakarsa masyarakat 
sendiri. Ini berarti bahwa kesadaran akan pentingnya pendidikan agama sudah mengakar dan memasyarakat (Marhalim, 2011).

Masyarakat dalam lingkup kecil adalah keluarga. Asumsi bahwa keluarga atau orangtua sebagai pendidik pertama dan terutama akan tetap berlaku, selebihnya bagi pendidikan agama karena disanalah penanaman fondasi perasaan keagamaan dan nilai-nilai moralitas agama yang selanjutnya akan dikembangkan dan dikukuhkan melalui proses pendidikan selanjutnya. Karena Islam menekankan bahwa orang tualah yang paling bertanggung jawab dalam pendidikan anak-anaknya termasuk pendidikan agamanya.

Pada umumnya penanaman nilai-nilai agama bermula dari asuhan keluarga. Akan tetapi peranan lingkungan juga sangat berpengaruh. Dan karena pendidikan itu suatu proses bertahap dan berkesinambungan yang dimulai sejak kanak-kanak sampai dewasa bahkan sampai akhir hayat maka upaya mencipta keluarga favourable untuk pendidikan agama tidak boleh diabaikan (Achmadi, 1992:108-118).

Adanya tanggapan positif tentang pendidikan agama Islam diranah Nasional menunjukkan bahwa pendidikan agama Islam merupakan suatu bidang ilmu yang perlu digarap dan dikembangkan baik oleh pemikir pendidikan Islam maupun para praktisi dalam menyongsong masa depan yang perlu diantisipasi sejak dini.

Prof. Achmadi juga memberikan berbagai pandangan tentang dasar dan yujuan pendidikan agama Islam. Dasar Pendidikan Agama Islam. Prof. Achmadi (1992:55) mengatakan bahwa pendidikan merupakan bagian sangat penting dari kehidupan dan, secara kodrati 
manusia adalah makhluk paedagogik. Maka dasar pendidikan yang dimaksud ialah nilai-nilai tertinggi yang dijadikan pandangan hidup suatu masyarakat atau bangsa dimana pendidikan itu berlaku. Karena yang dibicarakan pendidikan agama Islam maka pandangan hidup Islami atau pandangan hidup muslim yang pada hakekatnya merupakan nilai-nilai luhur yang bersifat transenden, universal dan eternal (abadi).

Berdasar pada nilai-nilai tersebut kedudukan ilmu pendidikan agama Islam sebagai ilmu yang normatif lebih dipertegas dan, karenaitu secara konseptual dapat dibedakan dengan ilmu pendidikan lain yang notabennya bukan berbasis Islam.

\section{Dasar dan Tujuan Pendidikan Agama Islam}

Dasar pendidikan ialah pandangan yang mendasari seluruh aktivitas pendidikan, baik dalam rangka penyusunan teori, perencanaan, maupun pelaksanaan pendidikan. Dalam hal ini adalah nilai-nilai tertinggi yang dijadikan pandangan hidup suatu masyarakat atau bangsa di mana pendidikan itu dilaksanakan. Oleh karena yang dibahas adalah pendidikan agama Islam, maka pandangan hidup yang mendasari seluruh kegiatan pendidikan ini adalah pandangan hidup yang Islami yang pada hakekatnya merupakan nilai-nilai luhur yang bersifat transenden, universal dan abadi yang bersumber dari al-Qur'an dan hadits yang shahih. Al-Qur'an dan Hadits mengandung banyak sekali nilai-nilai yang dapat dijadikan sebagai dasar pendidikan Islam. Diantara nilai-nilai dalam al-Qur'an dan Hadits yang dipandang fundamental, esensial, dan dapat merangkum berbagai nilai yang lain. 
Sumber nilai dalam Islam ialah al-Qur'an dan sunnah Rosul yang shahih. Karena banyaknya nilai yang terdapat dalam al-Qur'an dan Hadits dapat di klarifikasi kedalam nilai dasar atau intrinsik dan nilai instrumental. Nilai intrinsik adalah nilai yang ada dengan sendirinya bukan sebagai prasyarat atau alat bagi nilai yang lain. Mengingat begitu banyaknya nilai-nilai yang diajarkan oleh islam, maka perlu dipillih dan dibakukan nilai mana yang tergolong nilai intrinsik, fundamental dan memiliki posisi paling tinggi. Nilai tersebut adalah tauhid atau lebih tepatnya iman tauhid (Achmadi, 1992:56).

Tauhid secara etimologi berarti pengakuan terhadap keesaan Allah. Secara teologik, pengakuan tersebut mengandung kesempurnaan kepercayaan kepada Allah dari dua segi, dari segi rububiyah dan segi uluhiyah. Tauhid rububiyah ialah pengakuan terhadap keesaan Allah sebagai Dzat Yang Maha Pencipta, Pemelihara, dan memiliki semua sifat kesempurnaan seperti dalam QS. Al-Ikhlas. Sedang tauhid uluhiyah ialah komitmen manusia kepada Allah sebagai satu-satunya Dzat yang dipuja dan disembah dan satu-satunya sumber nilai. Komitmen kepada Allah itu diwujudkan dalam sikap pasrah, tunduk dan patuh, sehingga seluruh amal perbuatan dan hidup mati seseorang bertauhid semata-mata hanya untuk Allah (Achmadi, 1987:77-78).

Dalam disertasi Prof. Achmadi (1992:56) Formulasi tauhid yang paling singkat tetapi tegas ialah kalimah tayyibah "La ilaha illallah", yang artinya tidak ada tuhan selain Allah. Kalimat tayyibah merupakan kalimat penegas dan pembebas bagi manusia dari segala pengkultusan dan penyembahan, penindasan dan perbudakan sesama makhluk/manusia 
dan menyadarkan manusia mempunyai derajat yang sama dengan manusia lain. Tauhid sudah cukup bagi kehidupan umat manusia karena dalam pandanganhidup Islam, tauhid merupakan fondasi bangunan ajaran Islam dan tauhid dinilai yang paling esensial dan sentral untuk seluruh gerak hidup Muslim. Begitu pula dengan pendidikan agama Islam dijiwai dengan norma-norma fundamental dan sekaligus dimotivasi dan diberi nilai tambah oleh kepentingan 'ubudiyyah.

Dasar-dasar pendidikan agama Islam lainnya yang merupakan penjabaran dari dasar tauhid, karena pada dasarnya seluruh nilai dalam Islam berpusat pada tauhid, yakni dasar kedua kemanusiaan yang merupakan pengakuan akan hakekat dan martabat manusia. Hak asasi seseorang harus dihargai dan dilindungi, untuk merealisasikan hak asasi tersebut tidak dibenarkan pelanggaran terhadap hak asasi orang lain. Implikasinya dalam pendidikan adalah setiap orang memiliki hak dan kewajiban yang sam untuk memperoleh dan menyelenggarakan pendidikan.

Dasar yang ketiga yaitu kesatuan umat manusia. Banyak sekali AlQur'an menegaskan tentang kesatuan umat manusia. Bhineka tunggal ika yang pada dasarnya semua memiliki tujuan hidup untuk pengabdian kepada Allah. Dalam hubungannya dengan masalah global yang sedang marak sekarang ini seperti kejahatan dimana-mana, perang antar bangsa dan sebagainya maka Islam memberikan jalur penyelamat. Agama (Islam) tegak diatas kepercayaan kepada Dzat yang mutlak, yaitu Tuhan sebagai suatu orde tertinggi dan homogin. Alam ini sendiri merupakan orde moral Dzat yang mutlak dan merupakan norma pokok dan ideal. 
Dalam perspektif inilah Islam tampil sebagai agama keyakinan dan keseimbangan.

Dasar keempat adalah tawazun atau keseimbangan, secara khusus prinsip keseimbangan terlihat pada penciptaan dari Allah terhadap alam. Prinsip keseimbangan yang harus diperjuangkan dalam kehidupan khususnya melalui pendidikan antara lain; keseimbangan antara kepentingan dunia dan akhirat, keseimbangan kebutuhan jasmani dan rohani, kepentingan individu dan sosial, dan keseimbangan antara ilmu dan amal.

Dasar yang terakhir adalah rahmatan lil'alamin, dalam aktivitas pendidikan yang salah satu sasarannya adalah pengembangan ilmu pengetahuan, Islam berpandangan bahwa apapun yang dikembangkan tidak terlepas dari nilai Ilahi (Achmadi, 1992:57-59).

Berbicara tentang dasar pendidikan maka menjadi satu kesatuan mengenai tujuan pendidikan. Tujuan pendidikan adalah suatu perubahan yang diharapkan pada peserta didik setelah mengalami proses pendidikan baik dari tingkah laku individu dan kehidupan pribadi maupun kehidupan masyarakat dan alam sekitarnya dimana individu itu hidup. Tentu saja perubahan yang diinginkan ialah menuju ke arah perubahan yang lebih baik. Dalam Islam pun juga menganjurkan agar manusia mengubah diri jika menginginkan Allah mengubah nasibnya. Oleh karena itu usaha pendidikan dalam rangka mengubah dan mengembangkan manusia ke arah kesempurnaan keberadaannya dibimbing dan diarahkan sesuai dengan konsepsi Tuhan yang memiliki kebenaran dan kebaikan mutlak dan sesuai dengan fitarh manusia. 
Berdasarkan dari pengertian tujuan pendidikan diatas, maka tujuan pendidikan agama Islam menurut Prof. Achmadi dibagi menjadi tiga tahapan yaitu tujuan tertinggi/terakhir, tujuan umum dan tujuan khusus.

Tujuan tertingi/terakhir ini bersifat mutlak, yang sesuai dengan tujuan hidup manusia dan peranannya sebagai ciptaan Allah. Menjadi hamba Allah yang paling bertaqwa (beribadah kepada Allah) dalam hal ini, pendidikan ditujukan untuk mengantarkan peserta didik yang senantiasa beribadah kepada Allah. Tentu saja ibadah dalam arti yang seluas-luasnya, tidak hanya ibadah yang bersifat ritual, untuk itu pendidikan Islam harus mencakup dua hal; pertama, pendidikan harus memungkinkan manusia mengerti Tuhannya sedemikian rupa (ma'rifatullah), sehingga semua ibadahnya dilakukan dengan penuh penghayatan akan keesaan dan kebesaran Allah. Kedua, pendidikan harus menggerakkan kemampuan-kemampuan manusia untuk memahami ilmu Allah yang tersirat dalam setiap fenomena di alam semesta, menggali untuk dimanfaatkan dan menggunakan semua ciptaan Allah untuk mempertahankan iman dan menopang agama Allah.

Mengantarkan peserta didik menjadi Khalifatullah fi al-ard (wakil Tuhan di bumi) yang mampu memakmurkan atau membudayakan alam sekitar dan sebagai konsekuensi setelah menerima Islam sebagai pedoman hidup. Dan memperoleh kesejahteraan, kebahagiaan hidup di dunia atau di akhirat, baik individu maupun masyarakat.

Prof. Achmadi juga mengkritisi relevansi Pendidikan Agama Islam Sekarang terkait dengan Materi Pendidikan. Pemikiran pendidikan agama Islam yang secara eksplisit membedakan dengan pemikiran lainnya. 
Mengenai manusia sebagai subyek dan obyek pendidikan didasarkan atas pandangan Islam tentang konsep fitrah, dasar tujuan pendidikan didasarkan atas nilai-nilai Ilahiyah dan insaniyah, begitu pula mengenai isi pendidikan.

Dalam mengaplikasikan pemikiran yang akan mengubah wajah dan kehidupan manusia. Karen Penner penulis trend mengenai agama antara lain mengatakan "Religion place in providing solace, in mediating ethical disputes, or celebrating moments when a relationship to the unknowable to the unknowable fills worshippers wth humanity." Seterusnya karen mengatakan "Religion transcends the ebb and flow of human progress and events, absorbing knowledge the modern age bring and shrugging off its secularism." Disini terlihat betapa agama akan muncul kembali sebagai pegangan hidup manusia di tengah-tengah kemajuan ilmu pengetahuan.salah satu trend kemajuan ilmu pengetahuan ialah perkembangan "Artifical Intellegence" (AI) di mana komputer dewasa ini masih kurang kompleks dibandingkan dengan otak cacing tanah. Kecepatan komputer akan menjadi dobel setiap 18 bulan sampai tahun 2012, dan pada tahun 2030 kecepatan komputer telah sama dengan seribu otak manusia, sedangkan pada tahun 2050 kecepatannya menjadi sama dengan 1 milyar otak manusia. Di dalam tulisan ini berbicara mengenai pengembangan pendidikan Agama Islam.

Para pakar pendidikan Agama Islam mempunyai gambaran yang belum jelas mengenai perkembangan pendidikan Agama Islam tersebut. Umumnya mereka beranggapan bahwa pendidikan Agama Islam masih menghadapi hambatan yang besar, ialah sifatnya yang tertutup dan sangat 
ortodoks dan belum terbuka untuk kemajuan ilmu dan teknologi. Di pihak lain perubahan yang besar sedang terjadi di sekitar pendidikan Agama Islam yang mau tidak mau harus menghadapi dan mengharuskan mengubah diri agar pendidikan Agama Islam menjadi salah satu pendidikan alternatif di dunia Indonesia (Tilaar, 2000:146-145).

Pendidikan agama Islam sekarang terkait Posisi PAI di ranah Kerangka Pendidikan Nasional juga menjadi kajian dari pemikiran Prof. Achmadi. Menjadikan pendidikan Islam sebagai salah satu pendidikan alternatif membutuhkan paradigma-paradigma baru untuk meningkatkannya, antara lain peningkatan manajemen pendidikan Islam. Pendidikan Islam di Indonesia telah berjalan lama dan mempunyai sejarah yang panjang. Namun demikian, dirasakan pendidikan agama Islam tersisih dari sistem pendidikan nasional. SKB 3 Menteri 24 Maret 1975 yang tersohor itu berusaha mengembalikan ketertinggalan pendidikan Islam untuk memasuki mainstream pendidikan nasional. Pada waktu itu telah diidentifikasikan berbagai kelemahan pendidikan Islam seperti terlalu banyaknya mata pelajaran yang diarahkan, kualitas guru rendah, sarana pendidikan yang kurang, dan para peserta didik kebanyakan berasal dari keluarga yang kurang mampu. Hal ini berarti pendidikan Islam belum merupakan alternatif pendidikan modern.

Tersingkirnya pendidikan agama Islam dari mainstream pendidikan nasional, dapat mengakibatkan jatuhnya pendidikan Islam di dalam dua jenis dikotomi atau dualisme yang artifisial. Petama ialah dikotomi yang pendidikan yang sekuler dan pendidikan yang mempunyai ciri khas, dalam hal ini khas keislaman. Selanjutnya pendidikan agama 
Islam telah terperangkap dalam dualisme pengelolaan, antara pengelolaan pendidikan di bawah Departemen Pendidikan Nasional dan Departemen Agama.

Kedua jenis dikotomi atau dualisme yang artifisial tersebut lebih memperparah pengembangan pendidikan agama Islam atau lebih memurukkan pendidikan agama Islam dari arus perkembangan masyarakat di sekitarnya. Keadaan ini membawa usaha untuk meningkatkan mutu pendidikan agama Islam di dalam suatu dilema yang cukup sulit. Pertama, adanya suatu keinginan yang besar untuk mengadakan modernisasi pendidikan agama Islam yang disebut oleh Malik Fadjar sebagai kekuatan yang pragmatis di dalam pendidikan agama Islam. Sedangkan yang kedua merupakan permintaan perubahan dari arus globalisasi yang tidak terbendung lagi.

Pendidikan agama Islam diminta memberikan suatu usaha yang ekstra cepat dan tepat untuk menanggulanginya karena kalau tidak demikian maka pendidikan Islam akan kembali pada ortodoksi dan tidak dapat mengikuti perubahan yang didambakan oleh masyarakat. Untuk menelaah masalah ini perlu adanya kajian tentang visi, misi pendidikan Islam di indonesia (Tilaar, 2000:147-148).

Relevansi pendidikan agama Islam sekarang dengan pemikiran Pendidikan Agama Islam menurut Prof. Achmadi secara normatif tidak perlu dilakukan perubahan karena diyakini memuat nilai-nilai transendental yang memiliki kebenaran mutlak. Akan tetapi dalam rangka menyusun strategi yang relevan dengan perubahan perlu di 
lakukan interpretasi nilai-nilai yang terkandung di dalamnya seperti peningkatan kualitas SDM.

\section{Simpulan}

Posisi pendidikan agama Islam di Indonesia semakin terlihat dengan adanya UU mengenai Sisdiknas no 20 tahun 2003, sejalan dengan hal tersebut pendidikan agama Islam menurut Prof. Achmadi mencakup dasar dan tujuan yang sesuai dengan nilai-nilai Ilahi. Pemikiran Prof. Achmadi seperti pendekatan fungsional, pendekatan humanis, pendekatan rasional kritis, pendekatan kultural dalam pendidikan agama Islam dapat dilakukan untuk memajukan pendidikan agama Islam di Indonesia dalam jangka panjang.

Materi pendidikan agama Islam menurut Prof. Achmadi terdiri dari perenial knowlegde dan ilmu yang diperoleh. Pendidikan agama Islam menurut Prof. Achmadi dengan PAI sekarang ini sangat relevan, akan tetapi masih membutuhkan peningkatan kualitas sumber daya manusia sebagai bentuk dari ideologi pendidikan yang berkembang sesuai dengan perubahan zaman yang tak terlepas dari nilai-nilai Islam sebagai pedoman dalam bertindak, mengamalkan nilai Islam mulai dari diri sendiri, keluarga, masyarakat, dan sebagainya.

Setelah dikaji secara mendalam pemikiran-pemikiran Prof. Achmadi terkait dengan pendidikan agama Islam diharapkan dan diterapkan di dunia pendidikan agama Islam di Indonesia untuk kemajuan pendidikan agama Islam di Indonesia. Baik dalam konteks pendidikan di dalam kelas ataupun skala nasional. 
Mudarrisa: Jurnal Kajian Pendidikan Islam, Vol. 7, No. 2, Desember 2015: 173-200

\section{Daftar Pustaka}

Achmadi. 1992. Islam Paradigma Ilmu Pengetahuan. Yogyakarta dan Semarang: Aditya Media dan BP IAIN Walisongo Press.

Marhalim. 2011. Media dalam Berdakwah (online), (http://ruangruhani.blogspot.co.id/, diakses 23 September 2014).

Moleong, Lexi J. 2006. Metode Penelitian Kualitatif. Bandung : Remaja Rosda Karya.

Munir, Misbachul. 2005. Pendidikan Islam Transformatif Dalam Perspektif Prof. Achmadi. Skripsi. Semarang: UIN Walisongo.

Nata, Abuddin. 2010. Metodologi Studi Islam. Jakarta: Raja Grafindo Persada.

Tilaar. 2000. Paradigma Baru Pendidikan Nasional. Jakarta: Rineka Cipta. 